\title{
Morphology of Dacryoconarida and landmarking of Placoparia and "odontochilinid" trilobites
}

Paleobiological working paper

Jakub Vodička ${ }^{1}$, Lukáš Laibl ${ }^{1,2}$, Petr Budil ${ }^{3}$, Oldřich Fatka ${ }^{1}$, Jan Toman ${ }^{4}$

1: Institute of Geology and Palaeontology, Faculty of Sciences, Charles University

2: Institute of Geology of the Czech Academy of Sciences

3: Czech Geological Survey

4: Department of Philosophy and History of Sciences, Faculty of Sciences, Charles University 
Fig. 1

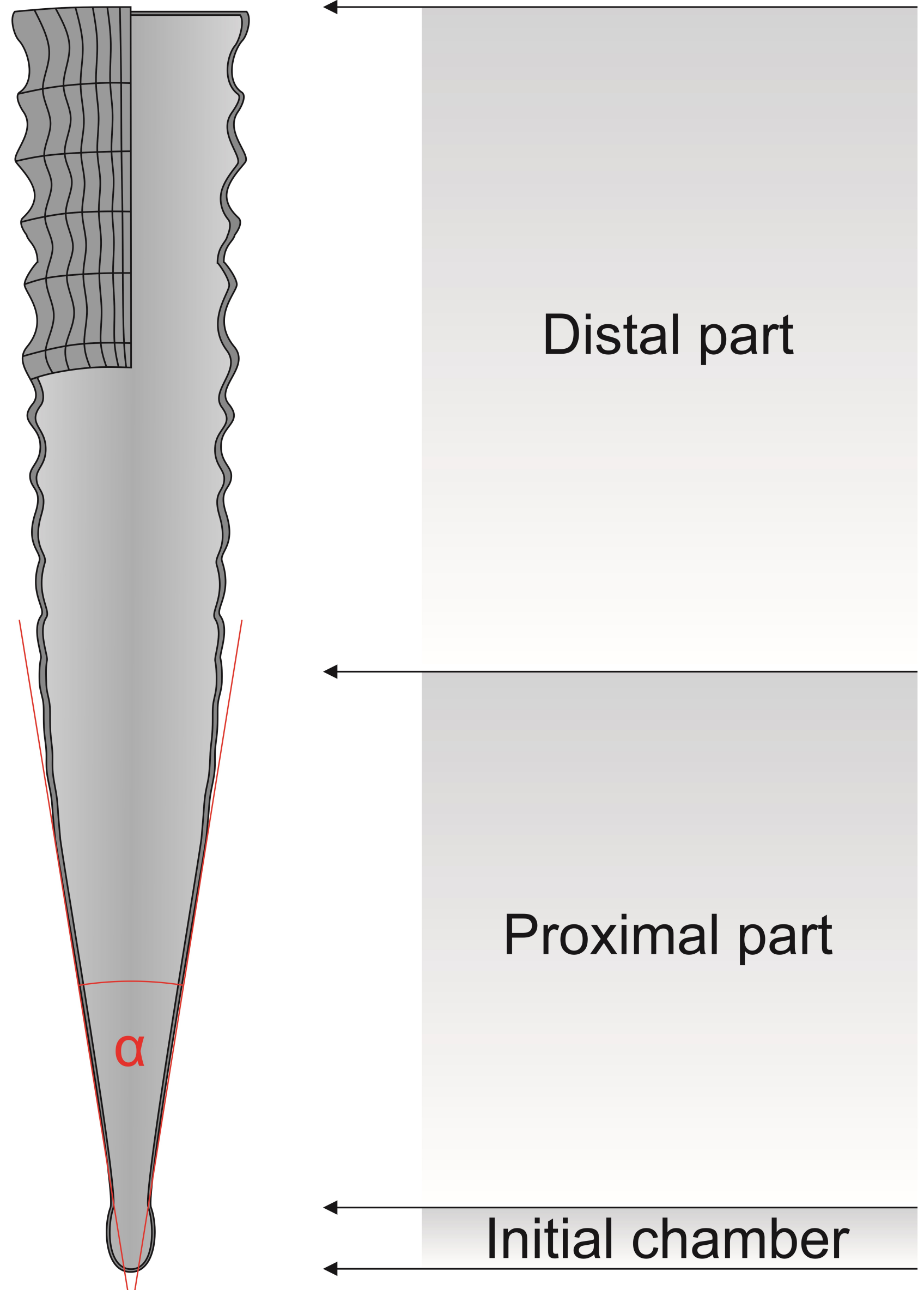




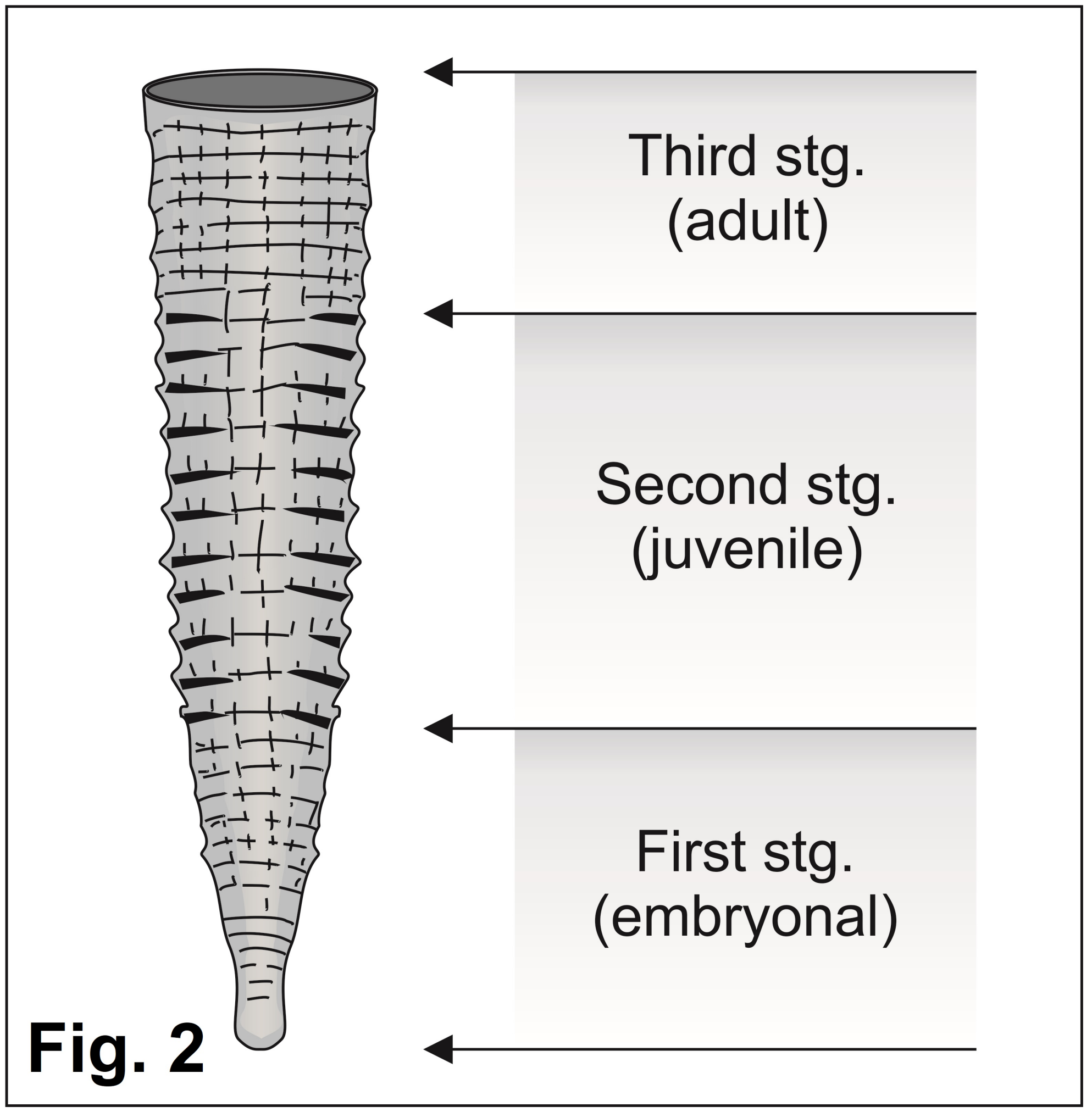


Fig. 3
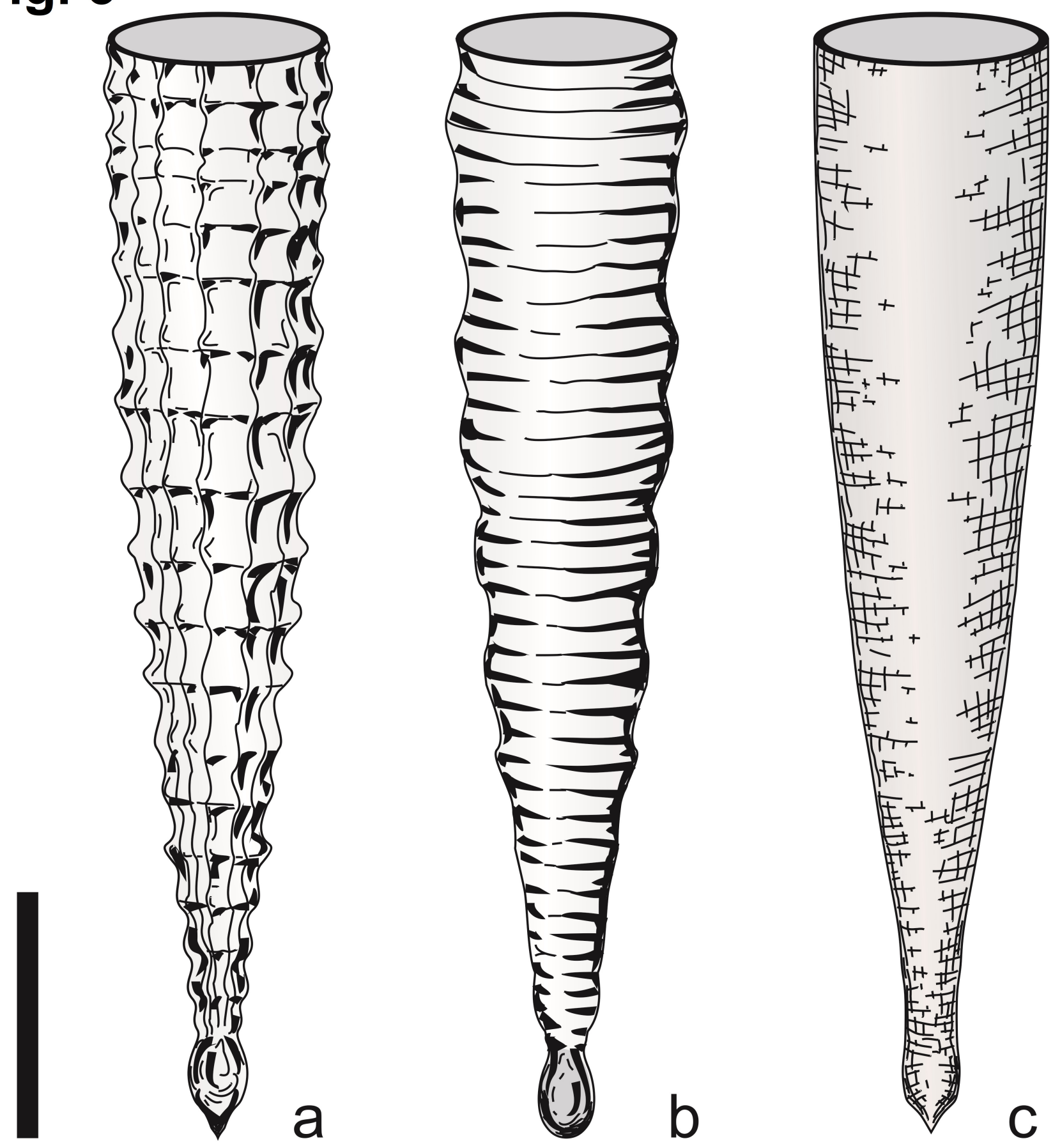


\section{Dacryoconarida}

Fig. 1

Generalized morphology of Dacryconarida, $\alpha$ represents apical angle. After Bouček, 1964.

Fig. 2

Ontogeny. Three phases of shell growing on Nowakia. After Bouček, 1964.

Fig. 3

Generalized morphology of three dacryoconarid genera emphasizing surface structures. After Gessa \& Lécuyer, 1998.

A: Nowakia, rings and ribs. B: Guerichina, rings. C: Styliolina, smooth surface. 


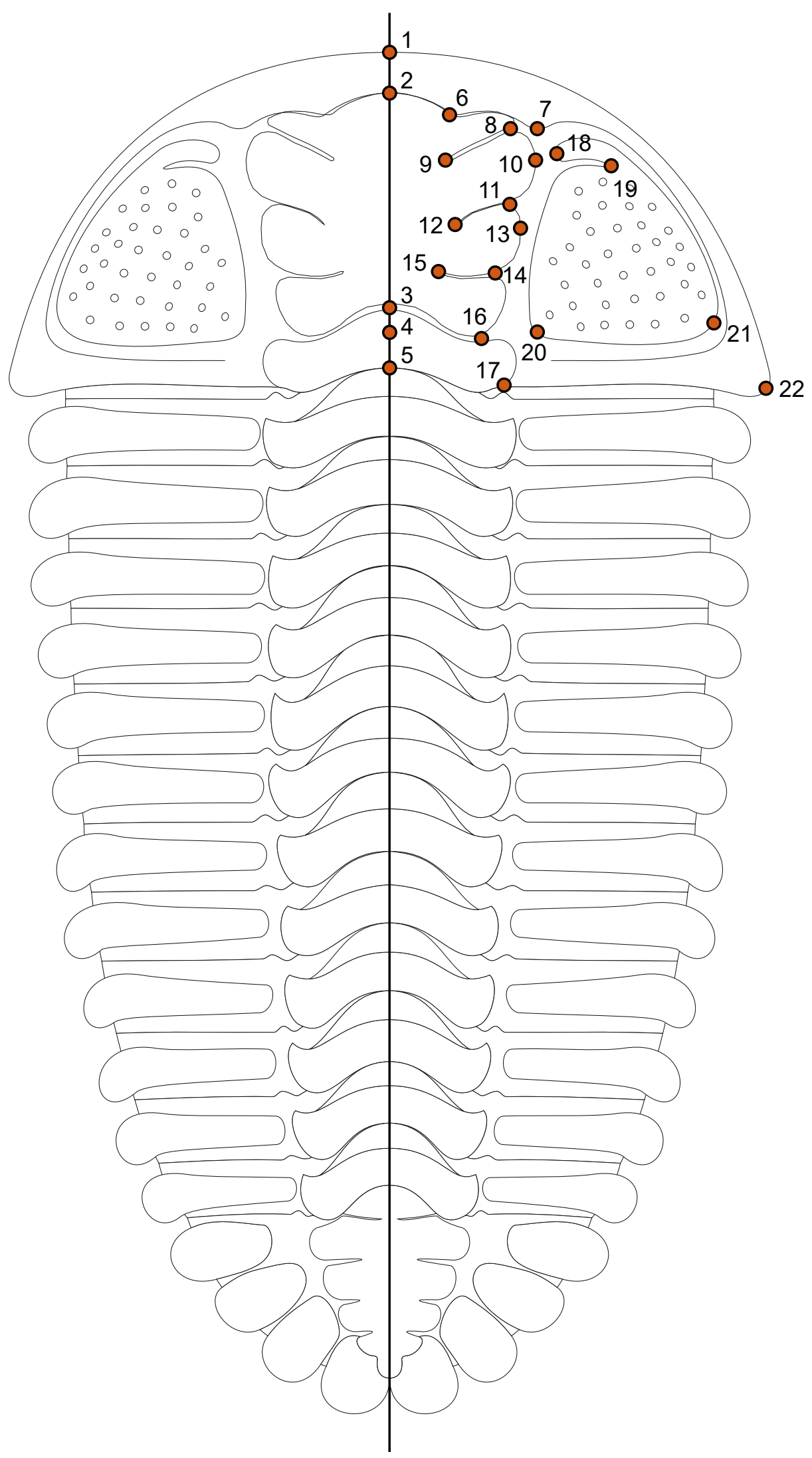




\section{Placoparia landmarks}

Cephalon

1 - anterior point of cephalon

2 - anterior point of glabella

3 - medial part of occipital furrow

4 - occipital node

5 - medial end of occipital ring

6 - maximal posterior curvature of anterior glabellar flexure

7 - maximal posterior curvature of anterior marginal flexure

8 - intersection of third glabellar furrow and axial furrow

9 - adaxial end of third glabellar furrow

10 - lateral extreme of third glabellar lobe

11 - intersection of second glabellar furrow and axial furrow

12 - adaxial end of second glabellar furrow

13 - lateral extreme of second glabellar lobe

14 - intersection of first glabellar furrow and axial furrow

15 - adaxial end of first glabellar furrow

16 - intersection of occipital furrow and axial furrow

17 - intersection of posterior margin of occipital ring and axial furrow

18 - medial extreme of anterior fixigenal ridge

19 - abaxial end of fixigenal furrow

20 - postero-medial edge of fixigenal field

21 - postero-lateral edge of fixigenal field

22 - lateral extreme of the cephalon 


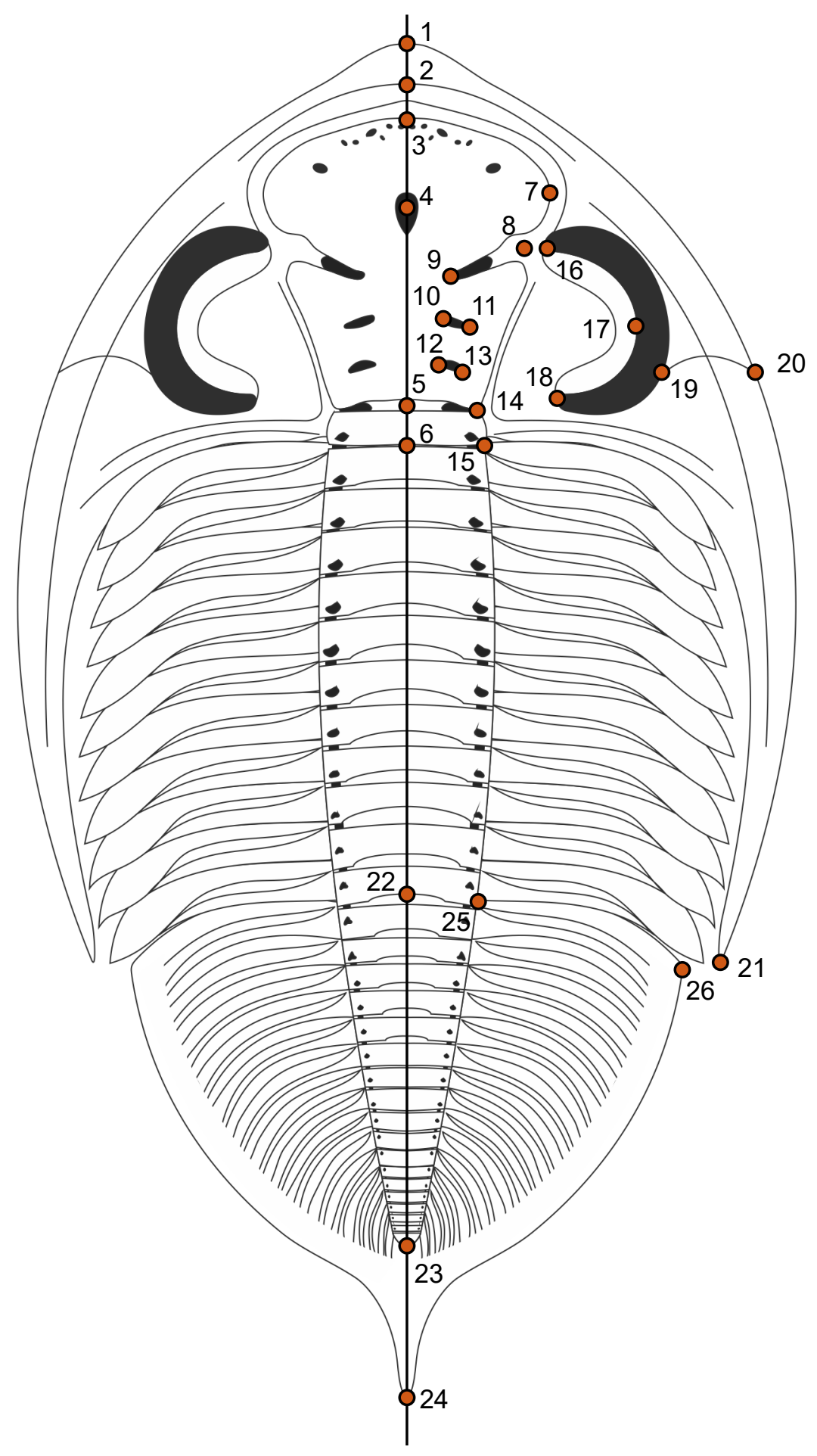




\section{Odontochile landmarks}

Cephahlon

1 - anterior point of cephalon

2 - anterior point of preglabellar field

3 - anterior point of glabella

4 - medial cephalic impression

5 - medial part of occipital furrow

6 - posterior end of occipital ring

7 - lateral extreme of glabella

8 - intersection of third glabellar furrow and axial furrow

9 - adaxial end of third glabellar furrow

10 - adaxial end of second glabellar furrow

11 - abaxial end of second glabellar furrow

12 - adaxial end of first glabellar furrow

13 - abaxial end of first glabellar furrow

14 - intersection of occipital furrow and axial furrow

15 - intersection of posterior margin of occipital ring and axial furrow

16 - anterior point of palpebral lobe

17 - lateral extreme of palpebral lobe

18 - posterior end of palpebral lobe

19 - intersection of eye socket and posterior branch of facial sututre

20 - intersection of lateral cephalic margin and posterior branch of facial sututre

21 - posterior tip of genal spine

Pygidium

22 - anterior point of pygidium

23 - posterior point of pygidial axis

24 - posterior point of pygidial spine

25 - intersection of anterior margin of first pygidial axial ring and axial furrow

26 - lateral extreme of pygidium 


\section{References}

Bouček, B. 1964. The tentaculites of Bohemia: Their morphology, taxonomy, ecology, phylogeny and biostratigraphy. Prague: Czechoslovak Academy of Sciences.

Gessa S., Lécuyer CH. 1998. Evolutionary dynamics of Pragian Dacryoconarida (Lower Devonian, Tentaculitoidea): evidence from paleontological data and $813 \mathrm{C}$ of marine carbonates from Czech Republic. Palaeogeogr. Palaeoclimatol. Palaeoecol. 138: 69-83. 